\title{
The Source, Distribution, and Sedimentary Pattern of K-Rich Brines in the Qaidam Basin, Western China
}

\author{
Xiangru Zhang ${ }^{1,2,3}$, Qishun Fan ${ }^{1,2}$, Qingkuan $\mathrm{Li}^{1,2,3, *}$, Yongsheng Du ${ }^{1,2, *}$, Zhanjie Qin ${ }^{1,2, *}$ \\ Haicheng Wei ${ }^{1,2}$ and Fashou Shan ${ }^{1,2}$ \\ 1 Key Laboratory of Comprehensive and Highly Efficient Utilization of Salt Lake Resources, \\ Qinghai Institute of Salt Lakes, Chinese Academy of Sciences, Xining 810008, China; \\ zhangxr@isl.ac.cn (X.Z.); qsfan@isl.ac.cn (Q.F.); hcwei@isl.ac.cn (H.W.); shanfsh@isl.ac.cn (F.S.) \\ 2 Qinghai Provincial Key Laboratory of Geology and Environment of Salt Lakes, Xining 810008, China \\ 3 University of Chinese Academy of Sciences, Beijing 100049, China \\ * Correspondence: liqingkuan@isl.ac.cn (Q.L.); dys@isl.ac.cn (Y.D.); qinzhanjie@isl.ac.cn (Z.Q.)
}

Received: 23 August 2019; Accepted: 24 October 2019; Published: 25 October 2019

\begin{abstract}
Potash plays an important role in agricultural production. The Qaidam Basin (QB) in western China is a typical inland evaporite basin, which contains an abundance of K-rich brines, including shallow brines (i.e., surface brines and intercrystalline brines) in salt lakes and deep brines (i.e., pore brines and oilfield brines) in the strata. Significant studies on these brines have been reported; however, the integrated studies on sources of $\mathrm{K}$, its distribution, and the sedimentary pattern of the two brine types are still inadequate. In this study, the $\mathrm{K}^{+}$concentrations of sixty-four intercrystalline brines from the Qarhan Salt Lake (QSL), the largest playa in the QB, are presented. After combining those results with the major ionic compositions of river waters and deep K-rich brines, and the $\mathrm{K}^{+}$ concentrations of shallow brines in the QB, we concluded that: (1) The K of brines in the QSL is mainly from the high-flux $\mathrm{K}$ input by rivers which gain $\mathrm{K}$ from silicate weathering, while the "ancient Qaidam Lake" contributed little K to the QSL; (2) the large K flux supplied by rivers, the appropriate concentration degree, and the mixing of river waters and spring waters, cooperatively account for the highest $\mathrm{K}$ concentrations of brines in the QSL in the QB. The different river $\mathrm{K}$ recharges in different sections and isolated depressions are responsible for uneven $\mathrm{K}^{+}$concentrations of brines in the QSL. (3) The deep brines are mainly distributed in the western QB. The K source of pore brines is from the interaction of pore water with the overlying evaporite layer. While the $\mathrm{K}$ in oilfield brines may be meteoric water, salt dissolution, the mixing of hydrothermal fluids, and the conversion of clay minerals to K-feldspar may consume $\mathrm{K}$ in the oilfield brines.
\end{abstract}

Keywords: K-rich brines; source; distribution; sedimentary pattern; Qaidam Basin

\section{Introduction}

Potassium (K) is an indispensable element for biological organisms [1]. Potash (a potassium compound) contains potassium in a water-soluble form and is used as chemical feedstock and in agricultural fertilizers [2]. Most of the giant potash deposits in the world exist in marine basins, such as the Saskatchewan potash deposit in Canada [3] and the potash deposit in the Zechstein Basin in Germany [2], while few are in the continental basins.

The Qaidam Basin (QB) in western China (Figure 1) is a typical terrestrial evaporite basin, which contains 28 saline lakes and playas with an area of $\sim 30,000 \mathrm{~km}^{2}$. Over the past several decades, many efforts have been directed toward investigating valuable elements ( $\mathrm{K}, \mathrm{B}, \mathrm{Li}$, etc.) [4-9] and evaluating the resource exploitation potential of salt lakes [10-13]. An abundance of shallow, K-rich brines, including the surface brines and intercrystalline brines, occur in these salt lakes (Figures 1 and 2), making the QB 
the largest potash fertilizer production base in China at present. In recent years, geological explorations have also reported that deep K-rich brines, including pore brines and oilfield brines, exist in the western QB (Figures 1 and 2) [13-21], which are of great importance for the future supply of potash fertilizers in China. All these shallow (including surface brines and intercrystalline brines) and deep brines (including pore brines and oilfield brines) in the QB have reached up to the industrial requirements $\left(\mathrm{K}^{+}>1.5 \mathrm{~g} / \mathrm{L}\right.$ for brines) in China [22]. Similarly, $\mathrm{K}$ reserves in the deep brines (pore brines and oilfield brines) are comparable to those of shallow brines (surface brines and intercrystalline brines) in the QB (Figure 3b); therefore, both these brines in the QB have great exploitation prospects. However, integrated studies and reviews focusing on the sources of $K$, and the distribution and sedimentary pattern of K-rich brines occurring in salt lakes and strata in the whole QB, are inadequate.

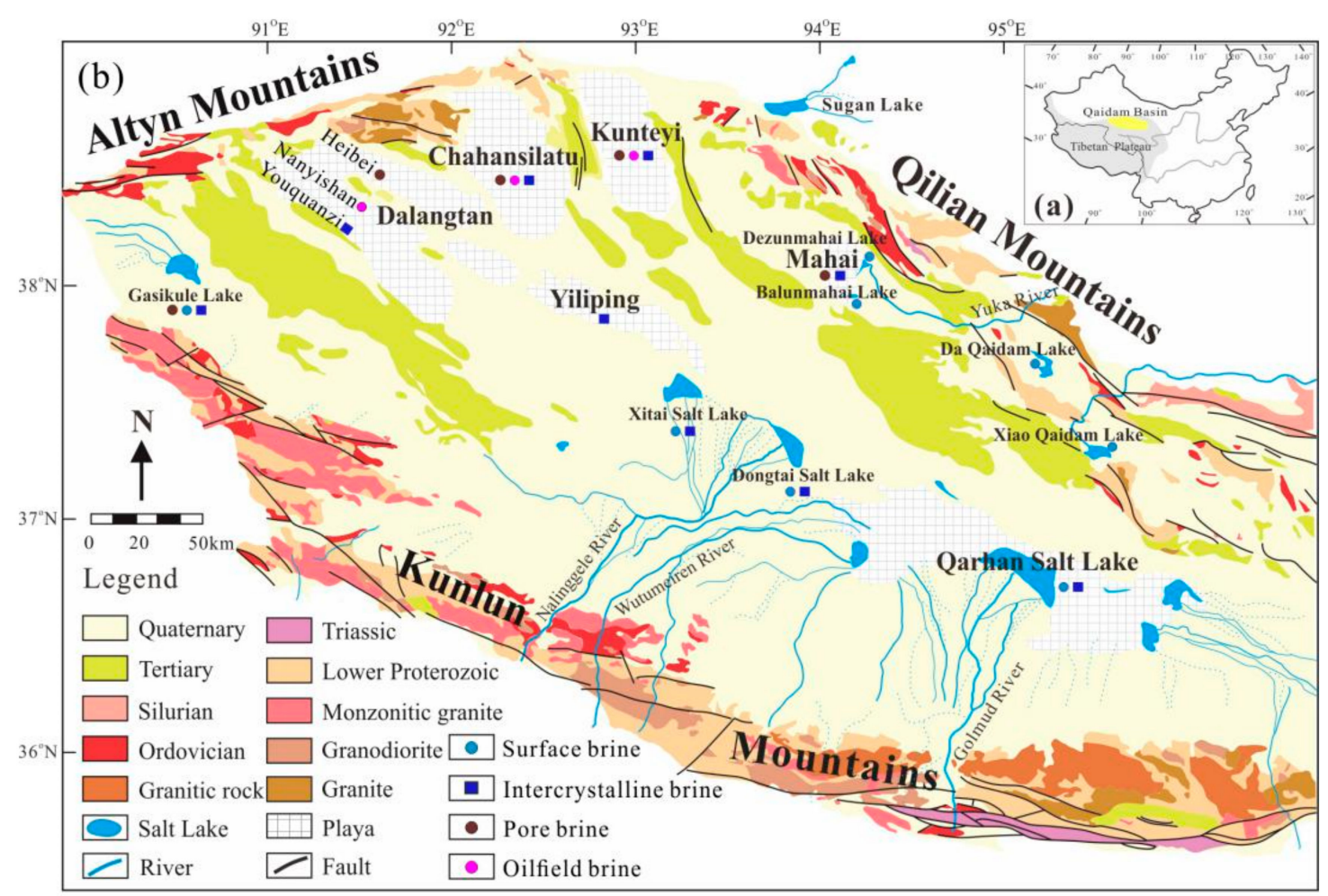

Figure 1. Geological map showing the study area: (a) the location of the Qaidam Basin (QB) in China; (b) geological map of the $\mathrm{QB}$ and its surrounding ranges. 


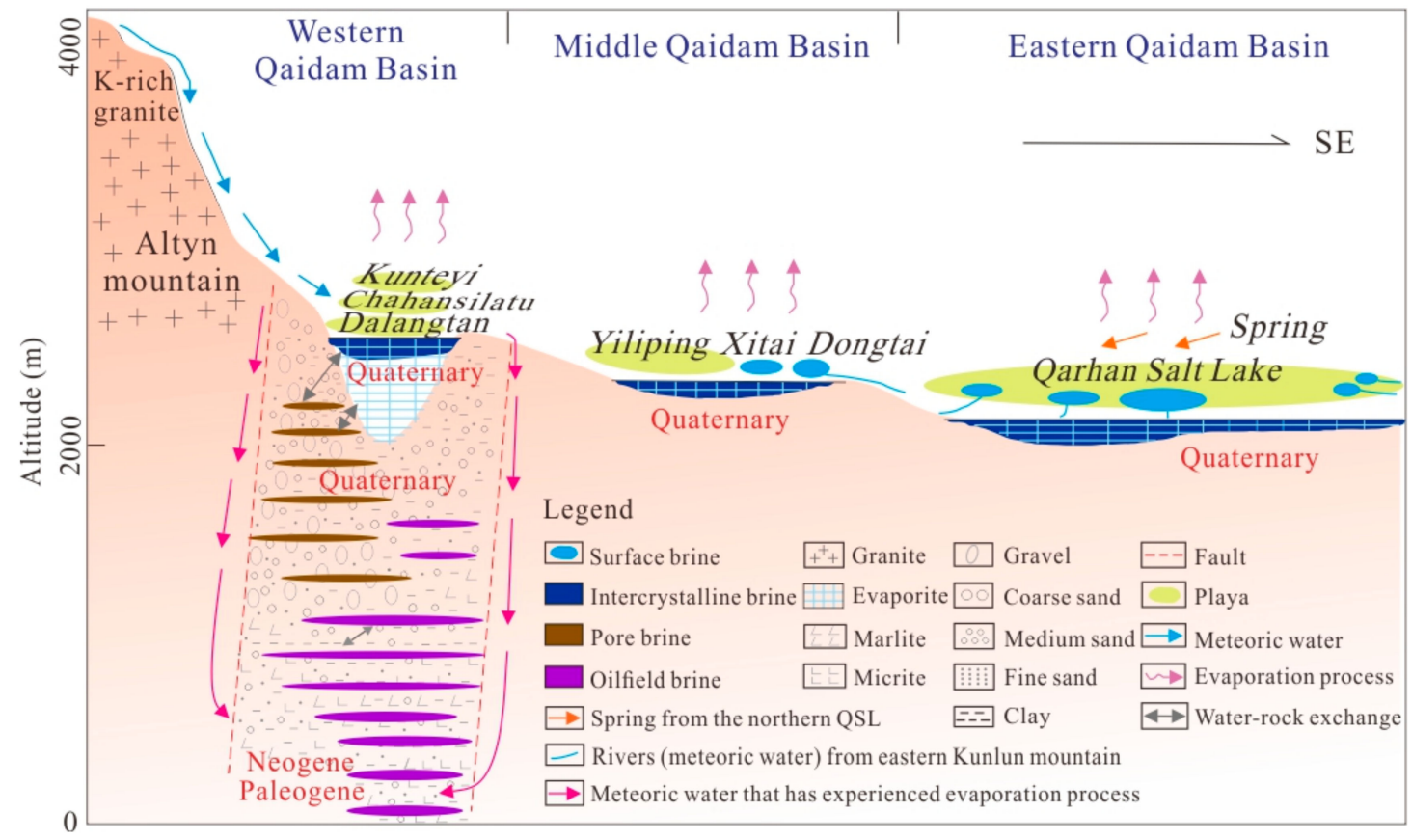

Figure 2. Distribution and origins of different types of K-rich brines in the QB.

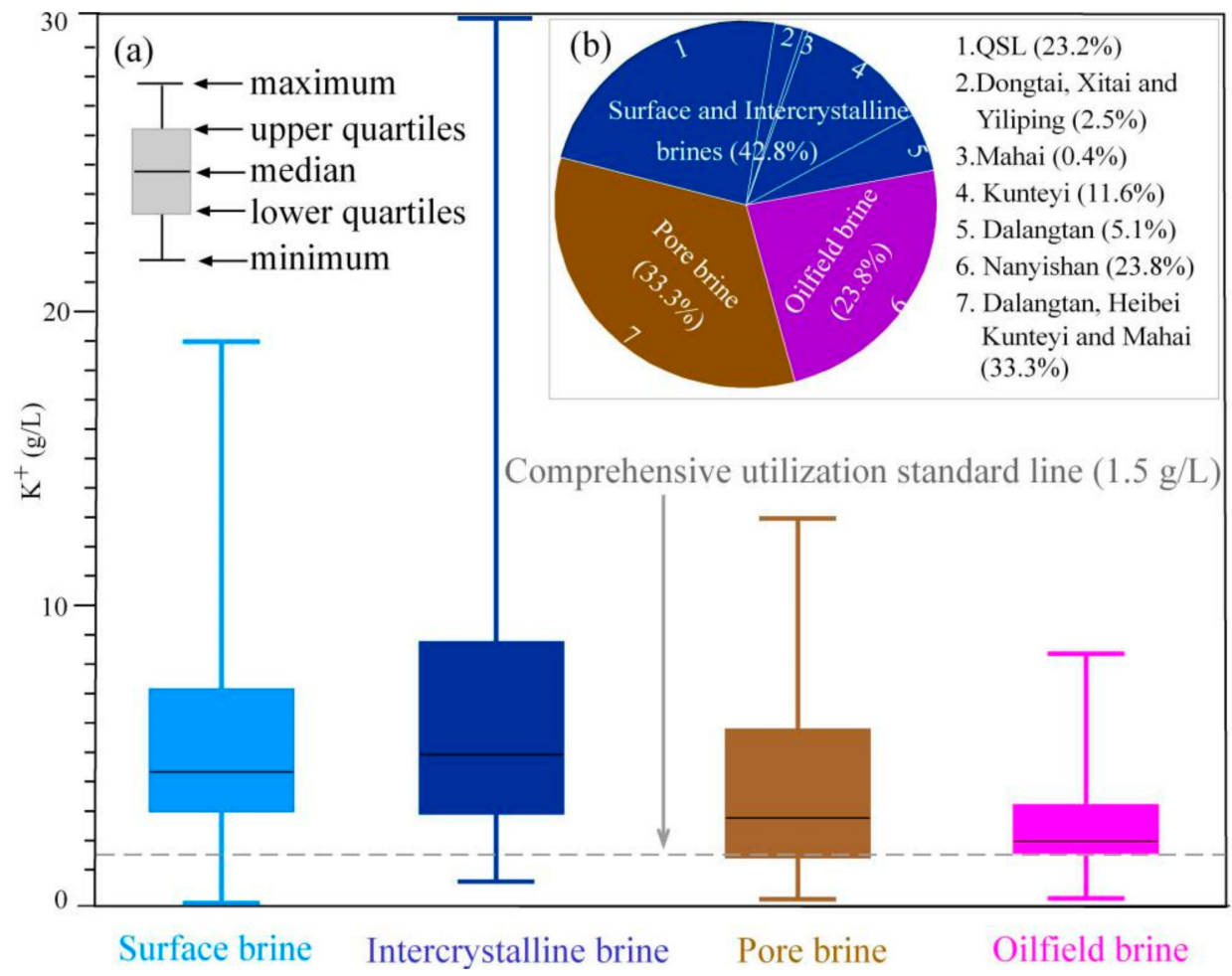

Figure 3. (a) Box-plot showing the $\mathrm{K}^{+}$concentrations of surface, intercrystalline, pore, and oilfield brines in the QB (the comprehensive utilization data from [22]); (b) the reserves of surface and intercrystalline brines, and pore and oilfield brines in the QB (the reserve data from [10]).

Here, sixty-four intercrystalline brines from the Qarhan Salt Lake (QSL) were collected and analyzed for the $\mathrm{K}^{+}$concentrations. Combining those results with the major ionic compositions of 102 river waters, 12 pore brines, and 54 oilfield brines, and the $\mathrm{K}^{+}$concentrations of 13 surface brines and 42 intercrystalline brines from different salt lakes in the $\mathrm{QB}$, this study aimed to (i) identify the fluxes and sources of $\mathrm{K}$ in the brines, and (ii) elucidate the distribution and sedimentary pattern of 
different types of K-rich brines in the QB. This study is important for understanding the formation of potash deposits in terrestrial evaporite basins.

\section{Description of the Study Area}

\subsection{Geological Setting of the $Q B$}

The QB $\left(35^{\circ} 55^{\prime}-39^{\circ} 10^{\prime} \mathrm{N}, 90^{\circ} 00^{\prime}-98^{\circ} 20^{\prime} \mathrm{E}\right)$, located in the northern part of the Qinghai-Tibetan Plateau, is a closed, fault-depressed basin with an irregular diamond shape (Figure 1). Three high mountains surround the basin, Qilian Mountain to the northeast, Altun Mountain to the northwest, and Kunlun Mountain to the south (Figure 1b). The embryonic QB formed during the Indosinian movement, and experienced major tectonic evolution during the Mesozoic [23,24]. Over 16,000 m of Mesozoic-Cenozoic sediments overlie the basement of the QB, which is composed by Paleozoic granites and Proterozoic-Paleozoic metamorphic rocks [25]. The combined presence of ambient high mountains (altitudes $>4000 \mathrm{~m}$ ) and a low basin (altitudes ranging 2600-3200 $\mathrm{m}$ ) in the QB favors the formation of salt deposits [4,7]. Thus, more than 20 salt lakes and an abundance of salt-brine resources are distributed throughout the basin [4].

Three large salt lake regions are present, from northwest to southeast in the western, middle, and eastern QB, respectively (Figure 1b). The Kunteyi, Chahansilatu, and Dalangtan playas in the western QB formed during the Neogene-early Pleistocene and are supplied by the waters from the Altun Mountain [4]. Only few surface saline lakes, such as Jiahu and Gasikule lakes, exist in this region. In the north side of the middle QB are the the Niulang, Balunmahai, and Dezunmahai salt lakes, and Mahai playa, which receive river water from the Qilian Mountain, whereas on the south side of the middle QB, the Yiliping playa, and Xitai and Dongtai salt lakes occur, and are fed by the Nalenggele River, originating from the Kunlun Mountain (Figure 1b). Similarly, in the north side of the eastern $\mathrm{QB}$, rivers rising from the Qilian Mountain feed the Da Qaidam and Xiao Qaidam salt lakes; and in the south side of the eastern QB, the QSL, which is the largest playa in the QB, is fed by the Kunlun Mountain river system and formed during the late Pleistocene [25-29].

In the western part of the $\mathrm{QB}$, deep pore brines, which occurred in the early Pleistocene strata (i.e., sand and gravel layers) at depths of 206-900 m, were also revealed in the Dalangtan-Heibei depression and the Kunteyi depression $[13,17]$. These brines spread to an area greater than $1000 \mathrm{~km}^{2}$ with a length over $100 \mathrm{~km}$ and a width of $8-16 \mathrm{~km}$. The $\mathrm{KCl}$ reserves of these brines are $\sim 3.5 \times 10^{8} \mathrm{t}$ [13]. In addition, oilfield brines occur in many tectonically-controlled anticlines, including the Nanyishan, Youshashan, Youdunzi, Youquanzi, and Xiaoliangshan anticlines in the Dalangtan playa, western QB, in the Paleocene-Oligocene strata (i.e., limestone, marlite and mudstone). These brines are usually $\mathrm{Ca}-\mathrm{Cl}$ type brines, enriched in trace elements $(\mathrm{B}, \mathrm{Li}, \mathrm{Br}, \mathrm{Rb}, \mathrm{Cs}$, etc.) and buried at the depth of $>500 \mathrm{~m}$ with temperatures close to $100{ }^{\circ} \mathrm{C}$ [16]. $\mathrm{K}$ reserves of different types of brines in different regions in the QB are shown in Figure 3b.

\subsection{Geological Setting of the QSL}

The QSL ( $\left.36^{\circ} 37^{\prime} 36^{\prime \prime}-37^{\circ} 12^{\prime} 33^{\prime \prime} \mathrm{N}, 93^{\circ} 42^{\prime} 36^{\prime \prime}-96^{\circ} 14^{\prime} 35^{\prime \prime} \mathrm{E}\right)$, with a total area of $5856 \mathrm{~km}^{2}$, is the largest playa in the eastern QB (Figures $1 \mathrm{~b}$ and 4). It spans $\sim 168 \mathrm{~km}$ from east to west and 20 to $40 \mathrm{~km}$ from north to south [4]. At the end of the late Pleistocene, a long scorpion-shaped structure, including the Yanhu and Yabaer anticlines, was formed from the neotectonic movement and the lake basin was formed [30]. Currently, the QSL is located in the Cenozoic subsidence belt of the QB [31]. The southern and northern margins of the QSL are controlled by the Chanan and Sanhu compresso-shear deep faults [30], respectively. 


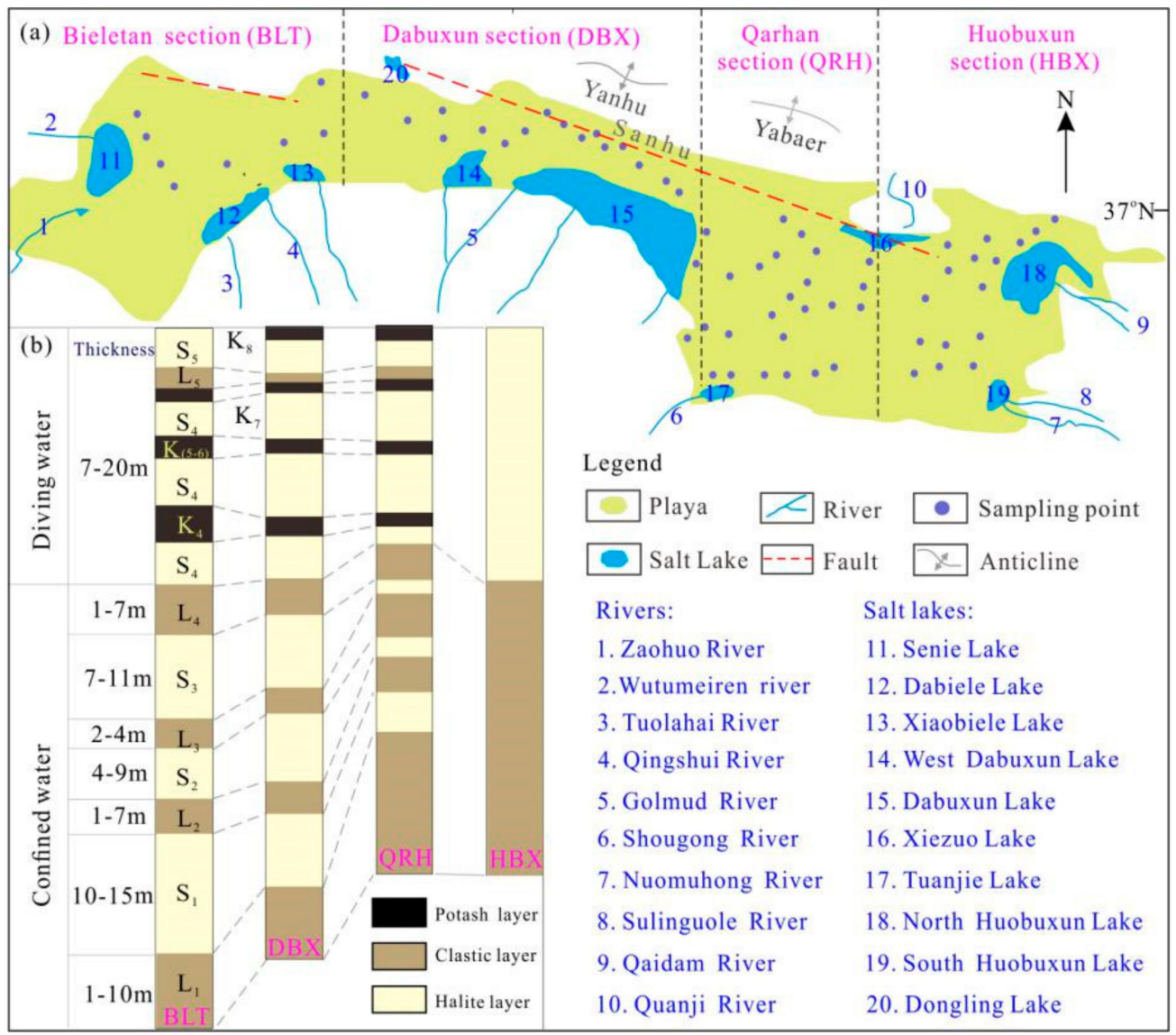

Figure 4. (a) The sampling sites; (b) spatial characteristics of salt deposits in the Qarhan Salt Lake (QSL): five halite-dominated evaporitic layers $\left(\mathrm{S}_{1}-\mathrm{S}_{5}\right)$ are separated by five clastic-dominated layers $\left(\mathrm{L}_{1}-\mathrm{L}_{5}\right)$. The layered, $\mathrm{K}$-bearing minerals are mainly enriched in the $\mathrm{S}_{4}\left(\mathrm{~K}_{4}-\mathrm{K}_{7}\right)$ and $\mathrm{S}_{5}\left(\mathrm{~K}_{8}\right)$.

Springs and rivers are the two main inflows replenishing the QSL $[9,27,32,33]$. The springs emerge along the fault in the north of the QSL and contain abundant $\mathrm{Ca}^{2+}$ and virtually no $\mathrm{HCO}_{3}{ }^{-}$. Meanwhile, there are ten main rivers (Wutumeiren, Zaohuo, Tuolahai, Qingshui, Golmud, Shougong, Nuomuhong, Qaidam, Sulinguole, and Quanji rivers) flowing into the lake [9] (Figure 4). Of them, the Golmud river, with a discharge of $7.98 \times 10^{8} \mathrm{~m}^{3} / \mathrm{y}$, is the largest river [7]. The rivers' waters are enriched in $\mathrm{SO}_{4}{ }^{2-}$, $\mathrm{Cl}^{-}$, and $\mathrm{Na}^{+}$, but are poor in $\mathrm{Ca}^{2+}$. The range of $\mathrm{K}^{+}$concentrations of the rivers is $2.7-122.2 \mathrm{mg} / \mathrm{L}$ (average $19.5 \mathrm{mg} / \mathrm{L}$ ), which is much higher than the world's average river water (3.9 $\mathrm{mg} / \mathrm{L}$ [7]).

The QSL contains ten surface salt lakes and a large area of playa (Figure 4). The salt lakes, including Senie, Dabiele, Xiaobiele, Dabuxun, West Dabuxun, Tuanjie, Xiezuo, North Huobuxun, and South Huobuxun lakes, exist in the margin of the playa where perennial or seasonal river recharge. All of the salt lakes are formed by the mixing of rivers and springs in different proportions [27,32,33]. For example, the Senie Lake, and Dabiele and Dabuxun lakes are mainly fed by rivers and form $\mathrm{Cl}-\mathrm{SO}_{4}$ type waters, while the Xiezuo and Dongling lakes contain $\mathrm{Ca}-\mathrm{Cl}$ type brines because they are mainly supplied by the springs. The playa is divided into the Bieletan, Dabuxun, Qarhan, and Huobuxun sections from west to east based on geological and mineral characteristics (Figure 4). Five halite-dominated evaporitic layers $\left(\mathrm{S}_{1}-\mathrm{S}_{5}\right)$, are separated by clastic-dominated layers $\left(\mathrm{L}_{1}-\mathrm{L}_{5}\right)$, deposited in the QSL. The thickness of the salt-bearing layer gradually decreases from 55 to $65 \mathrm{~m}$ in the easternmost Bieletan section to 15-25 $\mathrm{m}$ in the westernmost Huobuxun section (Figure 4). The solid K-bearing minerals (mainly sylvite $(\mathrm{KCl})$ and carnallite $\left(\mathrm{KCl} \cdot \mathrm{MgCl}_{2} \cdot 6 \mathrm{H}_{2} \mathrm{O}\right)$ ) in the QSL can be divided into two types according to its appearance: layered and disseminated [7]. The layered K-bearing minerals are mainly enriched in the $\mathrm{S}_{4}\left(\mathrm{~K}_{4}-\mathrm{K}_{7}\right)$ and $\mathrm{S}_{5}\left(\mathrm{~K}_{8}\right)$ and distribute in the eastern three sections (Figure 4), while the disseminated K-bearing minerals are present throughout the QSL from $S_{1}$ to $S_{5}$ [7]. 
An abundance of K-rich intercrystalline brines occur in the playa. The total reserves of $\mathrm{KCl}$ in the QSL are $5.4 \times 10^{8} \mathrm{t}$ [34], making it the largest modern potash deposit in the world and maintaining the largest potash fertilizer production base in China [4,35].

\section{Materials and Methods}

\subsection{Sample Collection and Analytical Method}

A total of 64 intercrystalline brine samples from the QSL were collected in this study, including 7 in the Bieletan section, 17 in the Dabuxun section, 27 in the Qarhan section, and 13 in the Huobuxun section (Figure 4). The samples were collected in $500-\mathrm{mL}$ polyethylene plastic bottles which were cleaned by dilute hydrochloric acid in the laboratory and rinsed with sample water. Then, the sample was filtered with a $0.45 \mu \mathrm{m}$ polypropylene membrane for analysis.

The $\mathrm{K}^{+}$concentrations of samples were determined by gravimetric methods through precipitation of potassium tetraphenylborate at the Qinghai Institute of Salt Lakes, Chinese Academy of Sciences [36]. Our experiments followed these instructions: Firstly, put $10 \mathrm{~mL}$ of each sample into a $100 \mathrm{~mL}$ beaker. Add $0.5 \mathrm{~mL}$ methyl red and appropriate amount of $0.05 \mathrm{M} \mathrm{HCl}$ to make the solution acidic. Then, add excess $1 \%$ sodium tetraphenylborate $\left(\mathrm{NaB}\left(\mathrm{C}_{6} \mathrm{H}_{5}\right)_{4}\right)$ solution to fully precipitate the $\mathrm{K}^{+}$. After that, filter the precipitated potassium tetraphenylborate $\left(\mathrm{KB}\left(\mathrm{C}_{6} \mathrm{H}_{5}\right)_{4}\right)$ and place it in an oven to dry at $105^{\circ} \mathrm{C}$. Finally, weigh the precipitate and calculate the $\mathrm{K}^{+}$concentration. Equation (1) is as follows:

$$
\mathrm{K}^{+}=W \times 0.1091 \times 10^{6} / V
$$

where $W$ is the weight of the precipitate and $V$ is the sample volume. The analysis error was less than $0.5 \%$.

\subsection{Data Analysis Methods}

\subsubsection{Flux Calculation}

To quantitatively calculate the total $\mathrm{K}$ supplying by rivers to the QSL, water-solute balance Equation (2) was applied in this study:

$$
\sum W=Q \times C
$$

where $\sum W$ is the annual $\mathrm{K}$ input into the QSL by each river; $Q$ is many years' average runoff for each river; $C$ is the average concentration of $\mathrm{K}^{+}$in each river.

\subsubsection{Forward Model to Quantify the Contribution of Different Sources to the Solutes of River Waters}

The possible sources of solutes in river waters mainly include the atmospheric water, rock (carbonate and silicate) weathering, and evaporite dissolution [37-39]. To identify how each of the above-mentioned sources contribute to the major ions in rivers, the forward model was applied. This model obtains the results by calculating the proportion of cationic charge derived from each source to the total major cation loads $\left(\mathrm{TZ}^{+}\right.$, meq/L) $\left(\mathrm{TZ}^{+}=\mathrm{Na}^{+}+\mathrm{K}^{+}+2 \mathrm{Mg}^{2+}+2 \mathrm{Ca}^{2+}\right.$, the unit of $\mathrm{Na}^{+}, \mathrm{K}^{+}, \mathrm{Mg}^{2+}$ and $\mathrm{Ca}^{2+}: \mathrm{mmol} / \mathrm{L}$ ) [40-43]. The outline of this model is shown in Figure $5 \mathrm{a}$ and the detailed calculation process is as follows. 


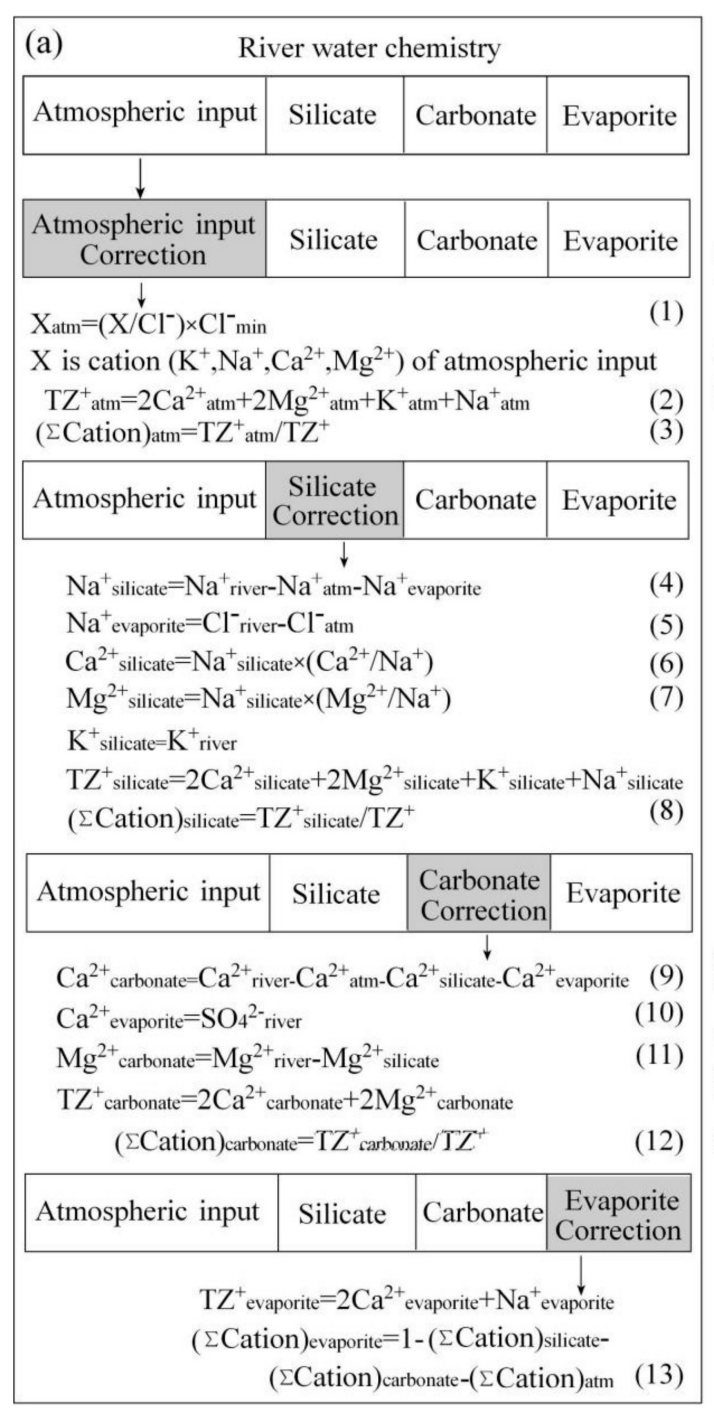

Forward model
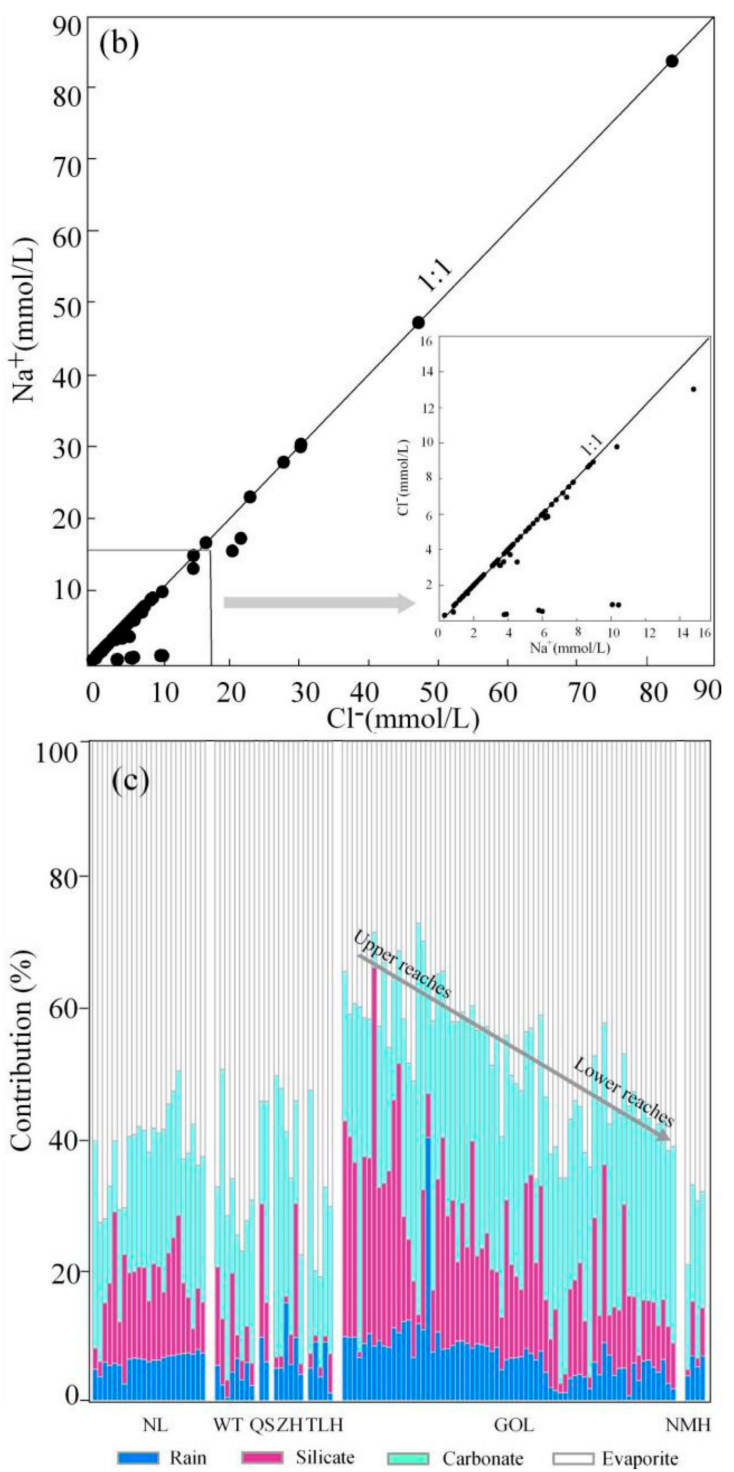

Figure 5. (a) An outline of the forward model used to calculate the contributing fractions of the each end-member. (b) The relationship between $\mathrm{Na}^{+}$and $\mathrm{Cl}^{-}$that corrected for atmospheric input. $\mathrm{Cl}^{-*}=\mathrm{Cl}^{-}$riv $-\mathrm{Cl}^{-}$atm; $\mathrm{Na}^{+*}=\mathrm{Na}^{+*}{ }_{\text {riv }}-\mathrm{Na}^{+*}$ atm. The subscripts riv and atm are river water and atmospheric input, respectively. (c) The proportional contributions of each end-member (atmospheric input, silicate, carbonate, and evaporite) to the rivers. NL-Nalenggele river; WT-Wutumeiren river; QS-Qingshui river; ZH—Zaohuo river; Gol-Golmud river; NMH-Nuomuhong river.

Atmospheric input: the portion of the major elements carried by atmospheric water was calculated first according to the first equation in Figure 5a [44], where $X_{\mathrm{atm}}$ is the corrected $\mathrm{K}^{+}, \mathrm{Na}^{+}, \mathrm{Ca}^{2+}$, or $\mathrm{Mg}^{2+}$ concentration' of rainwater. $(\mathrm{X} / \mathrm{Cl})_{\text {atm }}$ is the $\left(\mathrm{K}^{+}, \mathrm{Na}^{+}, \mathrm{Ca}^{2+}\right.$, and $\left.\mathrm{Mg}^{2+}\right) / \mathrm{Cl}^{-}$ratio in atmospheric water. $\mathrm{Cl}^{-}$min is the lowest concentration in atmospheric water. The total cations from atmospheric water $\left(\mathrm{TZ}^{+}\right.$atm $)$can be written as formula (2) in Figure 5a. Then, the percentage of total cations from the atmospheric water ( $\sum$ Cation) atm can be obtained (formula (3) in Figure 5a).

Silicate weathering: the silicate weathering can contribute $\mathrm{K}^{+}, \mathrm{Na}^{+}, \mathrm{Ca}^{2+}$, and $\mathrm{Mg}^{2+}$ cations to river water. $\mathrm{Na}^{+}$in the rivers is mainly from the atmospheric water, silicate weathering, and halite dissolution. According to mass balance, $\mathrm{Na}^{+}$provided by silicate weathering $\left(\mathrm{Na}^{+}\right.$silicate $)$can be estimated as $\mathrm{Na}^{+}$in rivers $\left(\mathrm{Na}^{+}{ }_{\text {river }}\right)$ minus the $\mathrm{Na}^{+}$from atmospheric water $\left(\mathrm{Na}^{+}{ }_{\text {atm }}\right)$ and evaporites $\left(\mathrm{Na}^{+}\right.$evaporite) (formula (4) in Figure 5a). Assuming that all $\mathrm{Cl}^{-}$in rivers corrected for atmospheric input $\left(\mathrm{Cl}^{-}\right.$river $-\mathrm{Cl}^{-}$atm $)$was from the dissolution of halite in the study area, another equation (formula (5) 
in Figure 5a) can be obtained and used to calculate the $\mathrm{Na}^{+}$silicate. All $\mathrm{K}^{+}$in rivers are assumed from the silicate weathering $\left(\mathrm{K}^{+}\right.$silicate $\left.=\mathrm{K}^{+}{ }_{\text {river }}\right) ; \mathrm{Ca}^{2+}$ and $\mathrm{Mg}^{2+}$ provided by the silicate $\left(\mathrm{Ca}^{2+}\right.$ silicate and $\mathrm{Mg}^{2+}$ silicate) are calculated assuming they are released to river waters in a fixed proportion relative to $\mathrm{Na}^{+}$silicate [45,46] (formulas (6) and (7) in Figure 5a). After that, the percentage of total cations from the silicate weathering ( $\sum$ Cation) $)_{\text {silicate }}$ was obtained (formula (8) in Figure $\left.5 a\right)$.

Carbonate weathering: the carbonate weathering mainly provides $\mathrm{Ca}^{2+}$ and $\mathrm{Mg}^{2+}$ to rivers. Assuming all $\mathrm{SO}_{4}{ }^{2-}$ in rivers after correction for rainwater are from the dissolution of gypsum, then, $\mathrm{Ca}^{2+}$ provided by the carbonate $\left(\mathrm{Ca}^{2+}\right.$ carbonate $)$ can be calculated by formula (9) in Figure $5 \mathrm{a}$. $\mathrm{Mg}^{2+}$ provided by the carbonate $\left(\mathrm{Mg}^{2+}\right.$ carbonate $)$ can be expressed as formula (11) based on mass balance. After that, the contribution of carbonate weathering was obtained (formula (12) in Figure 5a).

Evaporite dissolution: Evaporites mainly supply $\mathrm{Na}^{+}$and $\mathrm{Ca}^{2+}$ to rivers. The percentage of total cations from the evaporite dissolution is calculated by the formula (13) in Figure 5a.

\section{Results}

\section{1. $\mathrm{K}^{+}$Concentrations and TDS of Intercrystalline Brines in the QSL}

The results (Table 1) show that the $\mathrm{K}^{+}$concentrations of intercrystalline brines in the QSL range from 0.8 to $30.1 \mathrm{~g} / \mathrm{L}$, averaging $6.8 \mathrm{~g} / \mathrm{L}$. In detail, the highest $\mathrm{K}^{+}$concentration of intercrystalline brine in QSL appears in the northern part of the Dabuxun Lake and the lowest $\mathrm{K}^{+}$value is in the Qarhan section. The average $\mathrm{K}^{+}$concentrations in the Bieletan $(16.3 \mathrm{~g} / \mathrm{L})$ and Dabuxun $(9.8 \mathrm{~g} / \mathrm{L})$ sections are much higher than those in the Qarhan $(4.3 \mathrm{~g} / \mathrm{L})$ and Huobuxun $(3.0 \mathrm{~g} / \mathrm{L})$ sections. The contour map shows that the high $\mathrm{K}^{+}$concentrations appear near the river supplies, such as the Senie, Dabiele, Xiaobiele, West Dabuxun, and Dabuxun lakes, suggesting that the high $\mathrm{K}^{+}$concentrations may be related to the river inflows (Figure 6).

Table 1. The $\mathrm{K}^{+}$concentrations and TDS (total dissolved solids) of the intercrystalline brines in the QSL.

\begin{tabular}{cccccccc}
\hline Sample Site & No. & $\mathbf{K}^{+}(\mathbf{g} / \mathbf{L})$ & TDS $(\mathbf{g} / \mathbf{L})$ & Sample Site & No. & $\mathbf{K}^{+}(\mathbf{g} / \mathbf{L})$ & TDS (g/L) \\
\hline Bieletan & 1 & 11.5 & 336.1 & Qarhan & 33 & 1.6 & 427.0 \\
Bieletan & 2 & 21.1 & 343.9 & Qarhan & 34 & 0.9 & 406.4 \\
Bieletan & 3 & 10.8 & 379.9 & Qarhan & 35 & 0.8 & 416.8 \\
Bieletan & 4 & 10.2 & 320.1 & Qarhan & 36 & 4.1 & 333.3 \\
Bieletan & 5 & 18.5 & 327.6 & Qarhan & 37 & 10.1 & 366.7 \\
Bieletan & 6 & 15.4 & 330.8 & Qarhan & 38 & 2.8 & 337.3 \\
Bieletan & 7 & 26.5 & 393.3 & Qarhan & 39 & 4.4 & 315.2 \\
Dabuxun & 8 & 7.8 & 345.4 & Qarhan & 40 & 4.2 & 327.4 \\
Dabuxun & 9 & 12.7 & 352.1 & Qarhan & 41 & 3.0 & 310.7 \\
Dabuxun & 10 & 20.4 & 352.1 & Qarhan & 42 & 8.9 & 338.6 \\
Dabuxun & 11 & 5.1 & 307.2 & Qarhan & 43 & 3.6 & 314.6 \\
Dabuxun & 12 & 21.0 & 336.7 & Qarhan & 44 & 5.3 & 346.9 \\
Dabuxun & 13 & 8.2 & 338.6 & Qarhan & 45 & 4.5 & 331.5 \\
Dabuxun & 14 & 16.3 & 360.3 & Qarhan & 46 & 10.4 & 330.0 \\
Dabuxun & 15 & 3.0 & 330.2 & Qarhan & 47 & 5.3 & 356.8 \\
Dabuxun & 16 & 1.7 & 315.2 & Qarhan & 48 & 5.1 & 330.6 \\
Dabuxun & 17 & 4.5 & 391.5 & Qarhan & 49 & 3.0 & 312.5 \\
Dabuxun & 18 & 4.8 & 395.0 & Qarhan & 50 & 3.1 & 314.2 \\
Dabuxun & 19 & 3.4 & 352.4 & Qarhan & 51 & 4.6 & 320.4 \\
Dabuxun & 20 & 2.0 & 354.9 & Qarhan & 52 & 1.2 & 435.1 \\
Dabuxun & 21 & 2.0 & 379.7 & Qarhan & 53 & 3.1 & 309.9 \\
Dabuxun & 22 & 17.2 & 329.1 & Qarhan & 54 & 2.8 & 308.3 \\
Dabuxun & 23 & 30.1 & 339.3 & Qarhan & 55 & 5.2 & 325.8 \\
Dabuxun & 24 & 7.2 & 384.6 & Qarhan & 56 & 1.6 & 309.9 \\
Qarhan & 25 & 3.6 & 386.3 & Qarhan & 57 & 1.6 & 309.0 \\
\hline
\end{tabular}


Table 1. Cont.

\begin{tabular}{cccccccc}
\hline Sample Site & No. & $\mathbf{K}^{+}(\mathrm{g} / \mathrm{L})$ & TDS $(\mathrm{g} / \mathrm{L})$ & Sample Site & No. & $\mathbf{K}^{+}(\mathrm{g} / \mathrm{L})$ & TDS $(\mathrm{g} / \mathrm{L})$ \\
\hline Qarhan & 26 & 1.4 & 416.9 & Qarhan & 58 & 1.8 & 311.0 \\
Qarhan & 27 & 2.5 & 391.5 & Qarhan & 59 & 1.9 & 311.8 \\
Qarhan & 28 & 7.0 & 354.0 & Huobuxun & 60 & 1.5 & 313.6 \\
Qarhan & 29 & 8.9 & 366.5 & Huobuxun & 61 & 13.6 & 367.6 \\
Qarhan & 30 & 1.4 & 434.9 & Huobuxun & 62 & 1.7 & 308.6 \\
Qarhan & 31 & 5.9 & 362.1 & Huobuxun & 63 & 1.8 & 313.2 \\
Qarhan & 32 & 0.8 & 416.6 & Huobuxun & 64 & 1.9 & 311.0 \\
\hline
\end{tabular}

The total dissolved solids (TDS) of intercrystalline brines in the QSL are generally high, ranging from 307.2 to $435.1 \mathrm{~g} / \mathrm{L}$, averaging $359.4 \mathrm{~g} / \mathrm{L}$ (Table 1), which is about ten times higher than the TDS of modern seawater $(35.0 \mathrm{~g} / \mathrm{L}$ ) [7]. In detail, the average TDS in the Bieletan $(347.4 \mathrm{~g} / \mathrm{L})$, Dabuxun $(350.8 \mathrm{~g} / \mathrm{L})$, and Qarhan $(359.4 \mathrm{~g} / \mathrm{L})$ sections are comparable and higher than those in the Huobuxun $(325.0 \mathrm{~g} / \mathrm{L})$ section. The eastern part of the Dabuxun section, which is affected by the Golmud River, has lower TDS compared to the western part of this section. The $\mathrm{K}^{+}$concentrations and TDS of the intercrystalline brines are mismatched (Figure 6). High TDS does not correspond to high $\mathrm{K}^{+}$ concentrations in the QSL, especially in the Dabuxun section.

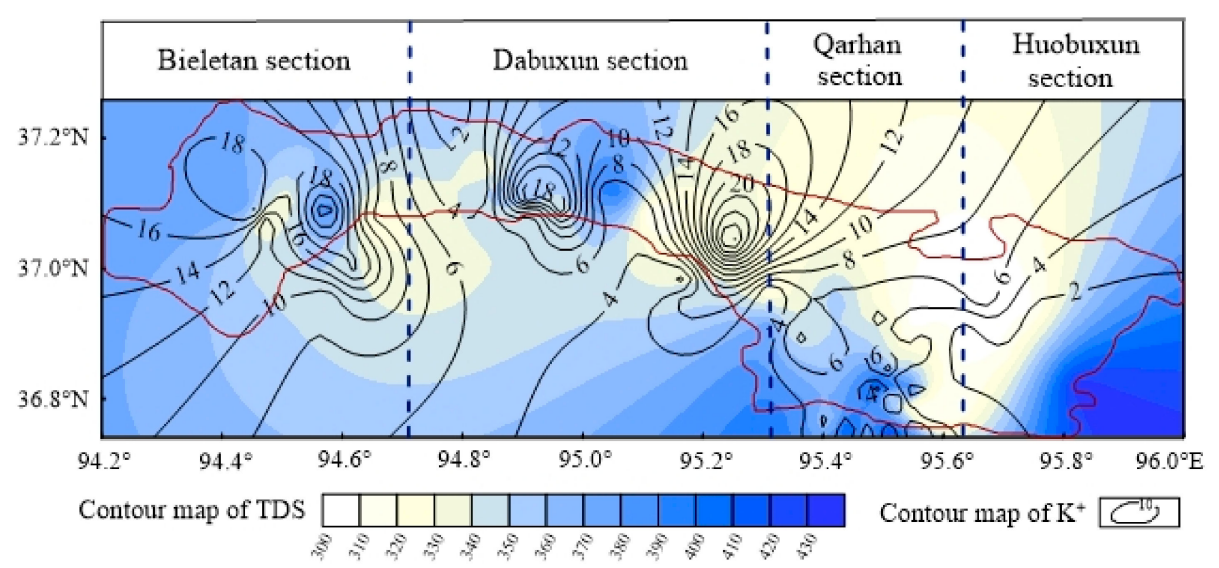

Figure 6. Contour map of $\mathrm{K}^{+}(\mathrm{g} / \mathrm{L})$ and TDS $(\mathrm{g} / \mathrm{L})$ of the intercrystalline brines in the QSL.

\subsection{K Flux Calculation}

The data of $\mathrm{Q}$ and $\mathrm{C}$ of each river are compiled from published data and shown in Table 2. Considering that the loss of $\mathrm{K}$ during the transportation process is $\sim 47 \%$ [7], the annual input of $\mathrm{KCl}$ into the QSL by each river was calculated (Table 2). The results show that in the QSL, the amount of K supplied by rivers gradually decreases from west to east (Table 2). 
Table 2. The total amount of $\mathrm{KCl}$ brought by rivers in the eastern Kunlun Mountain.

\begin{tabular}{|c|c|c|c|c|c|c|}
\hline Section & River & $Q\left(\mathrm{~m}^{3} / \mathrm{a}, 10^{8}\right)$ & $C(\mathrm{mg} / \mathrm{L})$ & $\begin{array}{c}\text { Total } \mathrm{KCl}^{\mathrm{a}} \\
\left(\mathrm{t} / \mathrm{a}, \mathbf{1 0}^{3}\right)\end{array}$ & $\begin{array}{c}\text { Total } \mathrm{KCl}^{\mathrm{b}} \\
\left(\mathrm{t} / \mathrm{a}, 10^{3}\right)\end{array}$ & $\begin{array}{c}\text { Total } \mathrm{KCl}^{\mathrm{c}} \\
\left(\mathrm{t} / \mathrm{a}, 10^{3}\right)\end{array}$ \\
\hline \multirow[t]{5}{*}{ Bieletan } & Wutumeiren R & 0.84 & 36.10 & 3.04 & 8.50 & 5.77 \\
\hline & Zaohuo R & 0.84 & 13.34 & 1.12 & 0.83 & 0.97 \\
\hline & Tuolahai R & 0.49 & 10.99 & 0.53 & 0.20 & 0.37 \\
\hline & Qingshui R & 0.36 & 3.85 & 0.14 & 0.86 & 0.50 \\
\hline & Total & & & 4.83 & 10.39 & 7.61 \\
\hline \multirow[t]{2}{*}{ Dabuxun } & Golmud R & 7.97 & 5.71 & 4.55 & 4.49 & 4.52 \\
\hline & Total & & & 4.55 & 4.49 & 4.52 \\
\hline \multirow[t]{2}{*}{ Qarhan } & Shougong R & & & & 0.57 & \\
\hline & Total & & & & 0.57 & 0.57 \\
\hline \multirow[t]{3}{*}{ Huobuxun } & Nuomuhong R & 1.54 & 2.70 & 0.42 & & \\
\hline & Sulinguole R & & & & 0.06 & \\
\hline & Total & & & & & 0.48 \\
\hline Spring & & & & & & 3.30 \\
\hline
\end{tabular}

$Q$ is average volume of many years' runoff [9]; $C$ is the average $K^{+}$concentration in a river $[4,6,7,9,11,47,48] .{ }^{a}$ The calculated data in this study; ${ }^{b}$ the data from [6]; ${ }^{\mathrm{c}}$ the average data of 1 and 2 . The data of total spring input data from [7].

\subsection{The Contributions of Four Sources to the Major Ions in Rivers}

The chemical compositions of each river are listed in Table S1. The results of the forward model (Figure 5c) demonstrate that the proportions of $\mathrm{TZ}^{+}$derived from the atmospheric input vary from $0.48 \%$ to $14.82 \%$ with an average of $6.5 \%$, indicating that the contribution of atmospheric input is minor. The average contributions from the carbonate weathering in the Wutumeiren, Qingshui, Tuolahai, Zaohuo, Golmud, and Nuomuhong rivers are $20.24 \%, 23.05 \%, 27.36 \%, 21.66 \%, 31.17 \%$, and $14.99 \%$, while those from the silicate weathering are $7.22 \%, 14.63 \%, 5.15 \%, 2.3 \%, 17.44 \%$, and $22.5 \%$, respectively. The calculations also reveal that the contributions of evaporites range from $44.28 \%$ to $70.56 \%$ in the whole study area. From the upper reaches to the lower reaches, the contributions of rock (silicate and carbonate) weathering decrease gradually, while those of evaporites increase (Figure 5c).

\section{Discussion}

\subsection{The Source of K in the QSL from Flux Calculation Constraint}

Previous studies on the formation of shallow K-rich brines (including surface brines and intercrystalline brines) in salt lakes in the QB have been reported. Chen and Bowler [26] proposed that the Qaidam "mega-paleolake" existed and migrated from west to east, followed by concentration of lake waters and formation of several salt lakes (from west to east, the Dalangtan, Chahansilatu, Kunteyi, and Yiliping playas and the QSL). Zhang [4] concluded that the environment of "high mountains and deep basins, and oscillating drying and wetting" in the QB is conducive to the enrichment of $\mathrm{K}$ in salt lakes. Subsequently, the mixing model of different waters [7,9,27,32]; the capture of paleolakes in the Kunlun Mountain by rivers and the migration to the Qarhan paleolake [49,50]; and the evaporation pumping model [5], have been proposed to explain the formation of giant potash deposit in the QSL. None of those studies included a water-flux weighted $\mathrm{K}^{+}$concentration calculation in the salt lakes in the QB. Thus, a regional mass balance approach (Section 3.2.1.) was applied in the QSL in order to better understand the source of $\mathrm{K}$ in salt lakes in the QB.

Currently, there are two major water inflows (river water and spring water) into the QSL. The annual input of $\mathrm{KCl}$ into the QSL by each river was calculated and shown in Table 2. Assuming the constant input rate of river-sourced K over $\sim 50$ kys of salt precipitation in the QSL [9], the total amount of $\mathrm{KCl}$ brought by rivers is 659 million tons, which is higher than the proven reserves ( 540 million tons) of $\mathrm{KCl}$ in the QSL. Moreover, spring waters also bring $\mathrm{K}$ to the QSL. The total input of $\mathrm{KCl}$ by spring waters is about a quarter of the river waters (165 million tons, [7]). Thus, river water inflow should be the major source of $\mathrm{K}$ in the QSL. This is supported by the fact that many modern terminal lakes 
of large inland rivers, such as the Dongtai and Xitai salt lakes (supplied by Nalenggele River) in the middle QB (Figure 1b, [4]), and the Lop Nur Salt Lake (supplied by the Kongque River) in the Tarim Basin [51], contain K-rich brines.

Where does the $\mathrm{K}$ in rivers come from? The possible sources of solutes in river waters mainly include atmospheric input, evaporite dissolution, and rock (carbonate and silicate) weathering [37-39]. The main process that contributes K to the rivers in the QSL region will be discussed. Firstly, in the arid QB with little precipitation, atmospheric input is the main water source to the rivers but cannot be the major source of $\mathrm{K}$ because the $\mathrm{K}^{+}$concentrations $(0-0.38 \mathrm{mg} / \mathrm{L})$ of atmospheric water are much lower than the river waters $(3.85-36.11 \mathrm{mg} / \mathrm{L})$ (Table 2). Secondly, the $\mathrm{K}$ from the evaporites is also insignificant due to that after correction for atmospheric input, the strong positive correlation between $\mathrm{Cl}^{-}$and $\mathrm{Na}^{+}$(Figure $5 \mathrm{~b}$ ) indicates that the $\mathrm{Cl}^{-}$provided by the evaporite is mainly derived from halite rather than potassium chloride. The $\mathrm{K}$ in rivers is most likely derived from rock weathering, specifically, the silicate weathering, because carbonates only provide $\mathrm{Ca}^{2+}, \mathrm{Mg}^{2+}$, and $\mathrm{CO}_{3}{ }^{2-}$ to the rivers. In fact, there is a large area of granite outcrop in the eastern Kunlun Mountain and the average weight percentage of $\mathrm{K}$ in these rocks is as high as 3.5\% [4,6,7]. The granite leaching experimental results also showed that $\mathrm{K}$ in granite could be leached significantly by waters under normal pressure and temperature $[4,52]$. Moreover, under the "high mountains and deep basins" environment, the rate of rock weathering and denudation should be accelerated, which can be proven by the huge clastic sediments of the Qaidam Basin [4]. A large amount of $\mathrm{K}$ in the granites can be released under this weathering process $[4,52]$. Therefore, the weathering of granites is the main source of the $\mathrm{K}$ in the QSL.

To quantitatively investigate the contributions of the above-mentioned four sources (atmospheric input, evaporite dissolution, carbonate and silicate weathering) for the salt load $(\mathrm{K}, \mathrm{Na}, \mathrm{Ca}$, and $\mathrm{Mg})$ in rivers, the forward model was used (Section 3.2.2.). The results are shown in Figure $5 \mathrm{c}$ and Table S1. The silicate weathering, which process provide $\mathrm{K}^{+}$to rivers, accounts for on average $13.5 \%$ (Table S1) of the total dissolved cations.

In addition, previous studies $[4,26,53]$ have demonstrated that modern salt lakes in the $\mathrm{QB}$ are the result of the migration and evolution of the "ancient Qaidam Lake." From the Oligocene-Miocene-Pliocene-Pleistocene, the ancient Qaidam Lake migrated from the Dalangtan to Chahansilatu playas, further to Yiliping playa, and finally, to the QSL, which presents a reverse-S shape (Figure 7a) [8]. Did shallow K-rich brines (including surface brines and intercrystalline brines) in salt lakes in the eastern QB inherit K from the "ancient Qaidam Lake"?

The $\mathrm{K}^{+}$contour map (Figure $7 \mathrm{~b}$ ) of shallow brines (including surface brines and intercrystalline brines) in salt lakes in the QB shows that the high $\mathrm{K}^{+}$concentrations are distributed in the middle of the basin and present northwest-southeast direction, which is obviously contrary to the reverse-S evolution path. Therefore, the "ancient Qaidam Lake" contributed limited K to the QSL. The K-rich brines in the QSL mainly result from the evolution of inflowing river waters. 


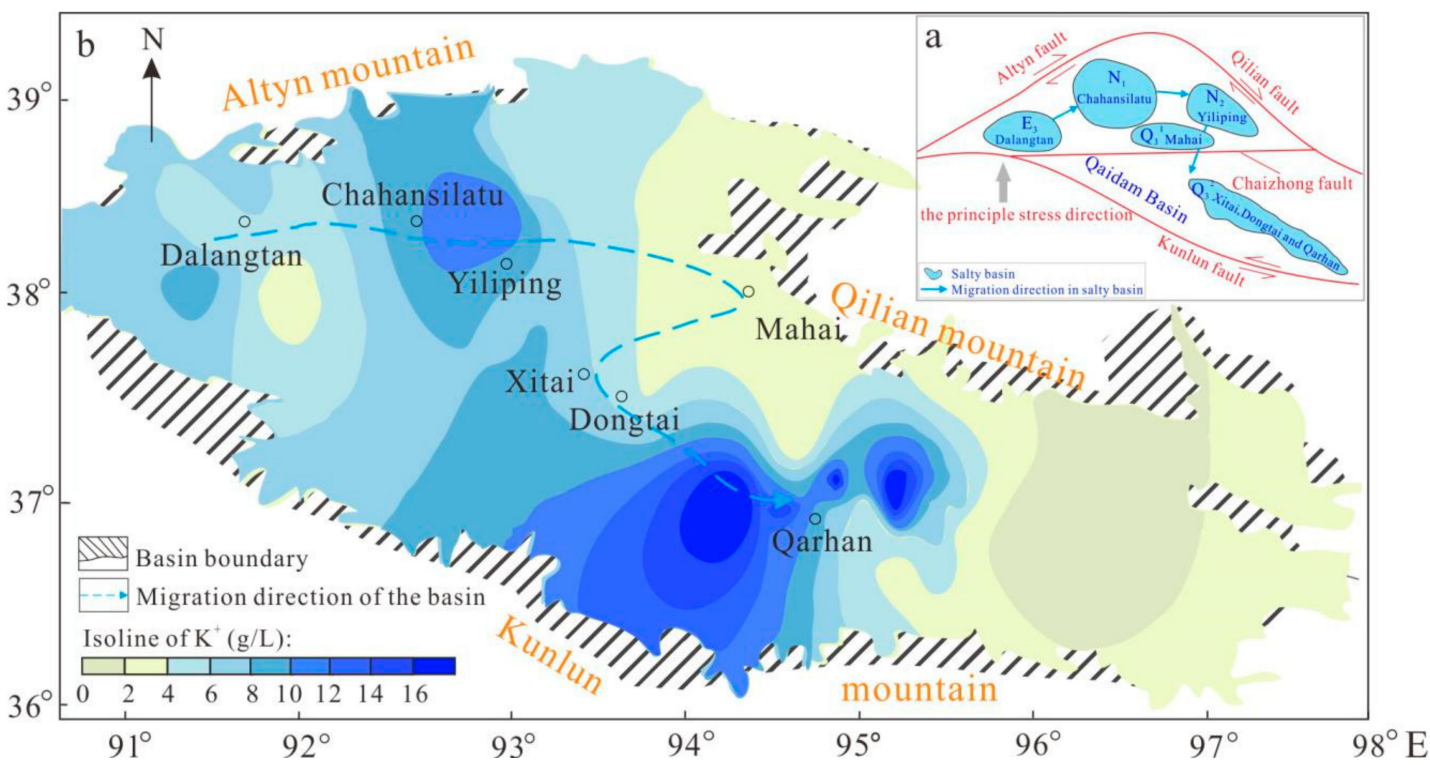

Figure 7. The evolution of salt lakes and the contours of $\mathrm{K}$ in salt lake brines in the QB: (a) the migration of the salt basins presents a reverse-S shape [8]; (b) the distribution of $\mathrm{K}^{+}$in the salt lake brines does not follow the reverse-S evolution path (data from Table 1 and Table S2).

\subsection{The Distribution and Sedimentary Pattern of Shallow Brines in the $Q B$}

Shallow brines include surface brine and intercrystalline brine (buried in evaporite layer with depth less than $100 \mathrm{~m}$ ) and occur at the whole part of the basin (Figure 1, Figure 2, and Figure 8a). The comparisons indicate that $\mathrm{K}^{+}$concentrations of shallow brines (surface brines and intercrystalline brines) are the highest in the QSL, ranging from 0.8 to $30.1 \mathrm{~g} / \mathrm{L}$. This enrichment should be interpreted by the following reasons. One is that rivers originating from the east Kunlun Mountain account for more than half of the total river runoff in the QB, which contributes more K to the QSL. The short flow distance of these rivers, indicating little $\mathrm{K}$ loss in the transportation paths, is also benefit to the $\mathrm{K}$ enrichment. Another is that the degree of evaporation and concentration of brines, revealed by the higher TDS (307.2-435.1 g/L, Table 1) than those in other salt lakes (Figure 8b), is appropriate for the $\mathrm{K}$ enrichment in brines in the QSL [6]. Yet another is that the mixing of two inflowing waters (river and spring waters) is conducive to the enrichment of $\mathrm{K}$ in the QSL. The mixing of the $\mathrm{SO}_{4}$-rich river water and Ca-rich spring water alters the chemical composition of a brine, resulting in a lack of the precipitation of K-bearing sulfate minerals [54], accelerating the enrichment of $K$ in the brines in the QSL $[9,27,32]$. 

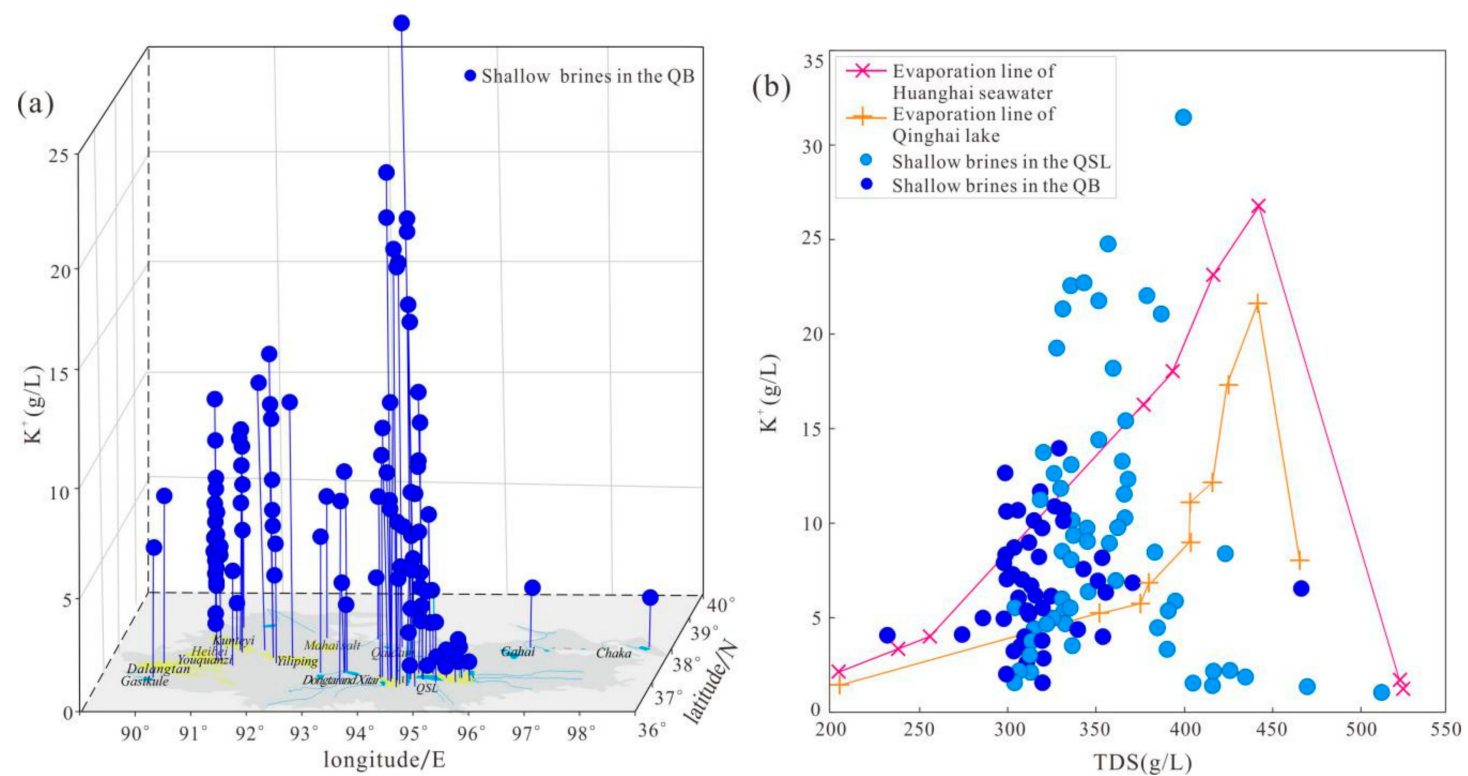

Figure 8. The shallow K-rich brines in the QB: (a) The $\mathrm{K}^{+}$concentrations and distribution of the shallow brines; (b) the relationship between $\mathrm{K}^{+}$concentrations and TDSs of the shallow brines.

In addition, $\mathrm{K}^{+}$concentrations of brines in different sections of the QSL are also uneven, and gradually decrease from the Bieletan section to the Huobuxun section (Table 1; Figures 3 and 8a). The K flux calculation shows that the total amount of $\mathrm{K}$ brought by rivers to each section can lead to this uneven distribution (Table 2). Among ten main rivers inflowing into the QSL, Wutumeiren, Zaohuo, Tuolahai, and Qingshui rivers supply the Bieletan section and provide the highest $\mathrm{K}$ flux (Table 2), which results into the highest $\mathrm{K}^{+}$concentrations in brines in this section (Table 1). Meanwhile, the QSL is divided into the Bieletan depression in the west and Dacha depression in the east by the Bieda uplift (Figure 9), which hinders hydrological connectivity of K-rich brines and produces uneven distribution of $\mathrm{K}^{+}$concentrations in brines in these four sections [55]. Therefore, different river $\mathrm{K}$ recharge in different sections and isolated depressions are responsible for uneven $\mathrm{K}^{+}$concentrations of brines in the QSL.



Figure 9. Map showing the isobath of lake basin and the source and enrichment mechanism of $\mathrm{KCl}$ in the QSL. 


\subsection{The Distribution, Source and Sedimentary Pattern of Deep Brines in the $Q B$}

The deep brines include pore brines and oilfield brines in the QB [18]. The pore brines have high TDSs of 200-350 g/L and their $\mathrm{K}^{+}$concentrations are 0.22-13.00 g/L (average: 3.76 g/L) (Table S2; Figure 10a) $[17,21]$. These brines are mainly distributed in the depressed basins; for example, the Mahai, Dalangtan, Heibei, Chahansilatu, and Kunteyi playas (Figures 1 and 10a). The reservoir of the pore brines is the early Pleistocene sand gravel layer and sand layer, overlaid by the Middle-Late Pleistocene evaporite and clay layer (Figure 2) [17]. The large reserves $\left(\sim 3.5 \times 10^{8} \mathrm{t}\right.$, [13]) and simple chemical compositions (mainly $\mathrm{KCl}$ and $\mathrm{NaCl}$ ) of the pore brines make it a promising $\mathrm{K}$ resource for the future. Meanwhile, the oilfield brines are also a very important $\mathrm{K}$ resource in the QB for their high $\mathrm{K}^{+}$concentrations (0.03-7.34 g/L, average $2.70 \mathrm{~g} / \mathrm{L}$; Table S2; Figure 3a) [14-16,19,20]. They mainly distributed in the Nanyishan and Shizigou anticline structure areas and occur in the Tertiary (Paleogene and Neogene) strata (Figures 1, 2 and 10a) [18]. The lithology of the reservoir for oilfield brines is sandstone, mudstone, siltstone, and marlite (Figure 2) [14-16,19,20].
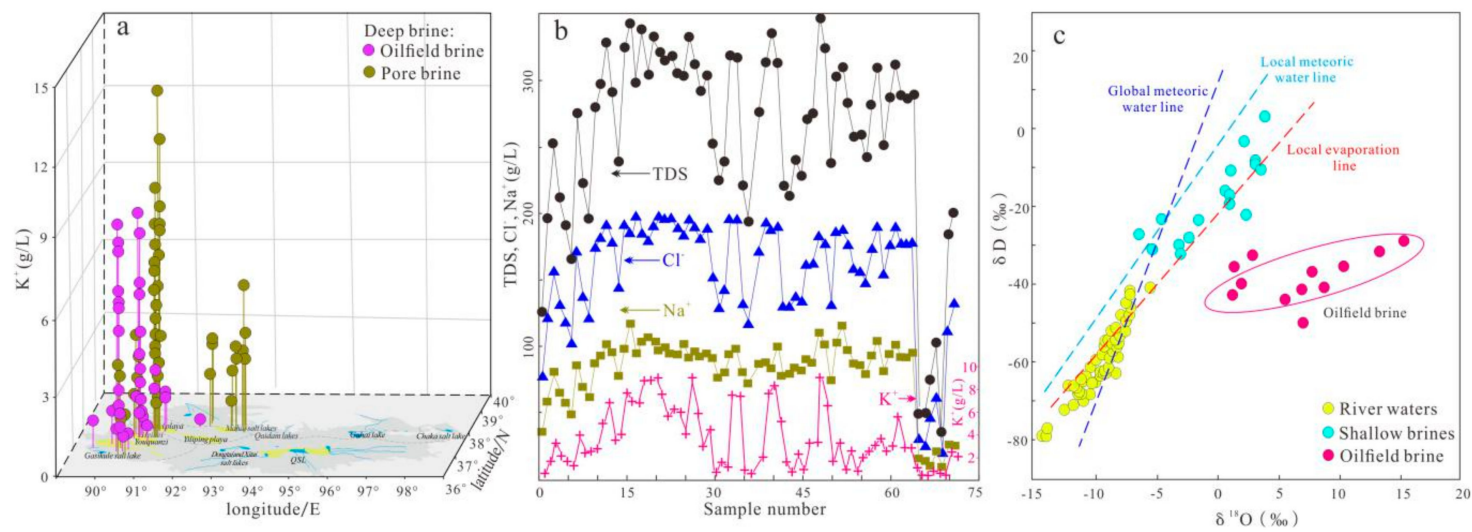

Figure 10. The deep K-rich brines in the QB: (a) The $\mathrm{K}^{+}$concentrations and distribution of pore brines and oilfield brines (data from Table S2); (b) the consistent variations of $\mathrm{K}^{+}, \mathrm{Na}^{+}, \mathrm{Cl}^{-}$, and TDS in each pore brine sample indicate that the $\mathrm{K}$ has the same source as $\mathrm{Na}, \mathrm{Cl}$, and TDS (data from Table S2); (c) the $\delta \mathrm{D}$ and $\delta^{18} \mathrm{O}$ values reveal that the oilfield brines were meteoric water origin, and experienced evaporation and water-rock interaction processes (global meteoric water line is from [56]; local meteoric water line is from [4]; the data of river waters are from [57,58]; data of surface and intercrystalline brines are from $[4,15]$; data of oilfield brines are from [15,16,19]; the local evaporation line is fitted in this study: $\left.\delta \mathrm{D}=3.5 \times \delta^{18} \mathrm{O}-21\right)$.

Previous studies [14-21] show that these two types of deep brines have different sources of $\mathrm{K}$ and experienced different evolution processes. The origin of the pore brines was interpreted by the fact that the buried pore water leached the overlying evaporite layer (mainly halite) and obtained solutes [17]. We compared the $\mathrm{K}^{+}, \mathrm{Na}^{+}$, and $\mathrm{Cl}^{-}$concentrations and the TDSs of these brines (Figure 10b), and found that the variations of these hydrochemical parameters have a consistent trend, implying that the source of $\mathrm{K}^{+}$is similar to that of $\mathrm{Na}^{+}, \mathrm{Cl}^{-}$, and TDS. Therefore, the water-salt interaction (original pore water with the overlying evaporites containing potash salts or K-rich intercrystalline brines) is responsible for the formation of the K-rich pore brines. By contrast, the origin of the oilfield brines is used to interpreted as meteoric waters according to the D-O isotopic evidence $[15,20]$. The meteoric waters generally experience salt dissolution, water-rock interactions, and the mixing of hydrothermal fluids when circulating the strata, supported by the $\mathrm{Na} / \mathrm{Cl}$ and $\mathrm{Br} / \mathrm{Cl}$ ratios, and $\mathrm{D}-\mathrm{O}-\mathrm{Sr}$ isotopes of the oilfield brines. The $\mathrm{K}$ in the oilfield brines may be derived from the meteoric waters, salt dissolution, and mixing of hydrothermal fluids. Meanwhile, the water-rock interaction may have depleted $\mathrm{K}$ in 
the oilfield brines according to the studies by Carpenter et al [59]. The loss of $\mathrm{K}^{+}$in the oilfield brines happened through the conversion of clay minerals (kaolinite or smectite) to K-feldspar [59-62]:

$$
\begin{gathered}
\text { Kaolinite }+\mathrm{K}^{+}+\mathrm{CaCO}_{3} \rightarrow \mathrm{K} \text {-feldspar }+\mathrm{Ca}^{2+} ; \\
\text { Smectite }+\mathrm{K}^{+} \rightarrow \mathrm{K} \text {-feldspar }+\mathrm{Na}^{+}+\mathrm{H}^{+} .
\end{gathered}
$$

These water-rock interactions are ubiquitous in the oilfield brines [59] and are evidenced by the positive excursion of $\delta^{18} \mathrm{O}$ (Figure 10c) $[14,15,63,64]$. This conclusion is also confirmed by the fact that the $\mathrm{Ca}^{2+} / \mathrm{Cl}^{-}(0.007-0.174$, average 0.03$)$ and $\mathrm{Na}^{+} / \mathrm{Cl}^{-}(0.50-1.62$, average 0.63$)$ ratios of oilfield brines are much higher than those of shallow brines (surface brines and intercrystalline brines) in salt lakes $\left(\mathrm{Ca}^{2+} / \mathrm{Cl}^{-}: 0.001-0.07\right.$, average $0.01 ; \mathrm{Na}^{+} / \mathrm{Cl}^{-}: 0.01-0.61$, average 0.23$)$ in the QB (Table S2). Moreover, the elevated K-feldspar contents in the Paleogene and Neogene strata can also verify these process $[53,65]$

\section{Conclusions}

The QB is a typical terrestrial evaporite basin, which contains an abundance of K-rich brines. These K-rich brines include the shallow brines in salt lakes (surface brines and intercrystalline brines) and deep brines (pore brines and oilfield brines) in the strata. The $\mathrm{K}^{+}$concentrations of 64 intercrystalline brines in the QSL, which is the largest playa in the QB, were analyzed. Combining these results with the previously-reported chemical compositions of river waters and deep brines (pore brines and oilfield brines), the $\mathrm{K}^{+}$concentrations of shallow brines (surface brines and intercrystalline brines) from different salt lakes in the QB, the source of $\mathrm{K}$, and the distribution and sedimentary pattern of $\mathrm{K}$-rich brines in the QB were compared. Several interpretations were made:

(1) The $\mathrm{K}$ in shallow brines (surface brines and intercrystalline brines) in the QB are mainly from high-flux $\mathrm{K}$ input by rivers which achieve $\mathrm{K}$ from silicate weathering, rather than from the remnant of the "ancient Qaidam Lake." The results calculated by using the forward model showed that evaporites contribute to most of the salt load $\left(\mathrm{K}^{+}, \mathrm{Na}^{+}, \mathrm{Ca}^{2+}\right.$, and $\left.\mathrm{Mg}^{2+}\right)$ in rivers in the QSL, followed by the carbonate and silicate weathering.

(2) The $\mathrm{K}^{+}$concentrations of shallow brines (surface brines and intercrystalline brines) in the QB are uneven. The amount of river $\mathrm{K}$ recharge, the appropriate evaporation degree, and the mixture of river and spring waters jointly contribute to this phenomenon. The uneven $\mathrm{K}^{+}$ concentrations of brines in the QSL result from different river $\mathrm{K}$ recharge in different sections and isolated depressions.

(2) The deep brines (pore brines and oilfield brines) are mainly distributed in the western QB. The water-salt interaction of original pore waters with the K-bearing evaporite layer (potash salts and/or K-rich intercrystalline brines) is the main reason for the formation of the K-rich pore brines. By contrast, the $\mathrm{K}$ in oilfield brines in the QB may be meteoric water, salt dissolution, and the mixing of hydrothermal fluids' origins, and the conversion of clay minerals to K-feldspar may consume $\mathrm{K}$ in the oilfield brines.

Supplementary Materials: The following are available online at http://www.mdpi.com/2075-163X/9/11/655/s1, Table S1: The chemical compositions of each river in the eastern Kunlun Mountain; Table S2: The chemical compositions of different types of brines in the QB.

Author Contributions: X.Z. analyzed the data and wrote the paper; Q.F., Q.L., Z.Q. and Y.D. discussed the results and contributed the central idea; H.W. and F.S. collected the samples and provided editing work.

Funding: This research was funded by the National Natural Science Foundation of China (grant number 41872093), the Open Research Project from the State Key Laboratory of Geological Processes and Mineral Resources, China University of Geosciences (GPMR201824), and the One-Thousand Innovative Talent Project of Qinghai Province (grant to QS Fan). 
Acknowledgments: We thank Liyan Shao for helping with the figure making. We are grateful to editors and reviewers for their meaningful suggestions.

Conflicts of Interest: The authors declare no conflict of interest.

\section{References}

1. Liu, C.L.; Wang, L.C.; Yan, M.D.; Zhao, Y.J.; Cao, Y.T.; Fang, X.M.; Shen, L.J.; Wu, C.H.; Lv, F.L.; Ding, T. The Mesozoic-Cenozoic tectonic settings, paleogeography and evaporitic sedimentation of Tethyan blocks within China: Implications for potash formation. Ore Geol. Rev. 2018, 102, 406-425. [CrossRef]

2. Warren, J.K. Evaporites through time: Tectonic, climatic and eustatic controls in marine and nonmarine deposits. Earth Sci. Rev. 2010, 98, 217-268. [CrossRef]

3. Klingspor, A.M. Middle Devonian Muskeg evaporites of western Canada. AAPG Bull. 1969, 53, 927-948.

4. Zhang, P.X. Salt Lake in Qaidam Basin; Science Press: Beijing, China, 1987.

5. Hsü, J.H.; Qian, Z.H.; Lian, W.; Yuan, Z.; Chen, Y.C.; Wu, B.H.; Wang, M.L. Origin of potassium evaporation pump in Qarhan Salt Lake, China. Geol. Chem. Miner. 1991, 12, 1-28.

6. Yang, Q.; Wu, B.H.; Wang, S.Z.; Cai, K.Q.; Qian, Z.H. Geology of Potassium Deposit in Qarhan Salt Lake; Science Press: Beijing, China, 1993.

7. Yuan, J.Q.; Yang, Q.; Sun, D.P.; Huo, C.Y.; Cai, K.Q.; Wang, W.D.; Liu, X.J. The Formation Conditions of Potash Deposit in Qarhan Salt Lake; Geological Press: Beijing, China, 1995.

8. Zheng, M.P.; Zhang, Y.S.; Liu, X.F.; Qi, W.; Kong, F.J.; Nie, Z.; Pu, L.Z.; Hou, X.H.; Wang, H.L.; Zhang, Z.; et al. Progress and prospect of salt lake research in China. Acta Geol. Sin. 2016, 4, 1195-1235. [CrossRef]

9. Fan, Q.S.; Lowenstein, T.K.; Wei, H.C.; Yuan, Q.; Qin, Z.J.; Shan, F.S.; Ma, H.Z. Sr isotope and major ion compositional evidence for formation of Qarhan salt lake, western China. Chem. Geol. 2018, 497, 128-145. [CrossRef]

10. Cao, W.H.; Wu, C. Brine Resources and the Technology of Their Comprehensive Utilization; Geology Press: Beijing, China, 2004.

11. Yu, S.S.; Liu, X.Q.; Tan, H.B.; Cao, G.C. Sustainable Utilization of Qarhan Salt Lake Resources; Science Press: Beijing, China, 2009.

12. Shi, Z.L.; Du, P.Y.; Wang, X.Q. Analysis and Study on Influential Factors of Potassium Chloride Production by Reverse Flotation. J. Salt Sci. Chem Ind. 2018, 47, 39-41.

13. Zheng, M.P.; Hou, X.H.; Zhang, Y.S.; Xing, E.Y.; Li, H.P.; Yin, H.W.; Yu, C.Q.; Wang, N.J.; Deng, X.L.; Wei, Z.; et al. Progress in the investigation of potash resources in western China. Geol. China. 2018, 3, 392-401. [CrossRef]

14. Fan, Q.S.; Ma, H.Z.; Tan, H.B.; Li, T.W.; Xu, J.X. Hydrochemical characteristics of brines and Potassium prospecting researches in Western Qaidam Basin. Acta Geosci. Sin. 2007, 5, 446-455.

15. Fan, Q.S.; Ma, H.Z.; Lai, Z.P.; Tan, H.B.; Li, T.W. Origin and evolution of oilfield brines from Tertiary strata in western Qaidam Basin: Constraints from ${ }^{87} \mathrm{Sr} /{ }^{86} \mathrm{Sr}, \delta \mathrm{D}, \delta^{18} \mathrm{O}, \delta^{34} \mathrm{~S}$ and water chemistry. Chin. J. Geochem. 2010, 29, 446-454. [CrossRef]

16. Tan, H.B.; Rao, W.B.; Ma, H.Z.; Chen, J.S.; Li, T.W. Hydrogen, oxygen, helium and strontium isotopic constraints on the formation of oilfield waters in the western Qaidam Basin, China. J. Asian Earth Sci. 2011, 40, 651-660. [CrossRef]

17. Li, H.P.; Zheng, M.P.; Hou, X.H.; Sun, B.T.; Liu, G.T.; Dou, Q.C. Hydrochemistry characteristics and origin of new brine sandy gravel in early Pleistocene of Heibei concave in Qaidam Basin. Earth Sci. J. China Univ. Geosci. 2014, 10, 1433-1442.

18. Li, H.P.; Zheng, M.P. Metallogenic characteristics of the potash deposit in deep brines in the western Qaidam Basin. Miner. Depos. 2014, 33, 935-936.

19. Li, J.S.; Li, T.W.; Peng, X.M.; Han, Y.H.; Li, Z.P.; Ma, H.Z. Hydrogeochemical behaviors of oilfield water in the Tertiary in western Qaidam Basin. Oil Gas Geol. 2014, 1, 50-61.

20. Li, H.P.; Zheng, M.P.; Hou, X.H.; Yan, L.J. Control factors and water chemical characteristics of potassium-rich deep brine in Nanyishan structure of western Qaidam Basin. Acta Geosci. Sin. 2015, 36, 41-50. [CrossRef]

21. Yue, X.; Liu, X.X.; Lu, L.; Zhang, X.D.; Fan, Z.L.; Yu, X.L. Hydrochemical characteristics and origin of deep pore brine deposit in Mahai Baisn. Acta Sedimentol. Sin. 2019, 1, 1-12. 
22. Li, W.; Dong, Y.P.; Song, P.S. Development and Utilization of Salt Lake Brine Resources; Chemical Industry Press: Beijing, China, 2012.

23. Guo, A.L.; Zhang, G.W.; Qiang, J.; Li, G.; Yao, A.P. An Indosinian Orogenic Belt in the Northeastern Qinghai-Tibet Plateau, China: Geochemical and Geochronological Evidence. Geochim. Cosmochim. Acta. 2008, 72, A335.

24. Tan, H.B.; Chen, J.; Rao, W.B.; Zhang, W.J.; Zhou, H.F. Geothermal constraints on enrichment of boron and lithium in salt lakes: An example from a river-salt lake system on the northern slope of the eastern Kunlun Mountains, China. J. Asian Earth Sci. 2012, 51, 21-29. [CrossRef]

25. Yin, A.; Rumelhart, P.; Butler, R.; Cowgill, E.; Harrison, T.; Foster, D.; Ingersoll, R.; Zhang, Q.; Zhou, X.Q.; Wang, X.F. Tectonic history of the Altyn Tagh fault system in northern Tibet inferred from Cenozoic sedimentation. Geol. Soc. Am. Bull. 2012, 114, 1257-1295. [CrossRef]

26. Chen, K.Z.; Bowler, J.M. Late Pleistocene evolution of salt lakes in the Qaidam Basin, Qinghai Province, China. Paleogeogr. Paleoclimatol. Paleoecol. 1986, 54, 87-104.

27. Zhang, P.X.; Zhang, B.Z.; Lowenstein, T.K.; Spencer, R.J. Origin of Ancient Anomalous Potassium Evaporites; Science Press: Beijing, China, 1993.

28. Fan, Q.S.; Ma, H.Z.; Wei, H.C.; Shan, F.S.; An, F.Y.; Xu, L.M.; Madsen, D.B. Late Pleistocene paleoclimatic history documented by an oxygen isotope record from carbonate sediments in Qarhan Salt Lake, NE Qinghai-Tibetan Plateau. J. Asian Earth Sci. 2014, 85, 202-209. [CrossRef]

29. Fan, Q.S.; Ma, H.Z.; Ma, Z.B.; Wei, H.C.; Han, F.Q. 2014b. An assessment and comparison of 230Th and AMS ${ }^{14} \mathrm{C}$ ages for lacustrine sediments from Qarhan Salt Lake area in arid western China. Environ. Earth Sci. 2014, 71, 1227-1237. [CrossRef]

30. Cai, K.Q.; Gao, J.H. Formation conditions of potassium deposit in Qarhan Salt Lake. Geosci. Front. 1994, 1, 3-4.

31. Duan, Z.H.; Yuan, J.Q. The origin of saline materials of Qarhan Salt Lake in Qaidam Basin, China. Geoscience 1988, 4, 420-428.

32. Lowenstein, T.K.; Spencer, R.J.; Zhang, P.X. Origin of ancient potash evaporites: Clues from the modern nonmarine Qaidam Basin of western China. Science 1989, 245, 1090-1092. [CrossRef]

33. Lowenstein, T.K.; Risacher, F. Closed basin brine evolution and the influence of $\mathrm{Ca}-\mathrm{Cl}$ inflow waters: Death Valley and Bristol Dry Lake California, Qaidam Basin, China, and Salar de Atacama, Chile. Aquetic Geochem. 2009, 15, 71-94. [CrossRef]

34. Wang, S.J. Prospects for tapping the resources of the Qarhan Salt Lake. Geol. Chem. Miner 1999, 3, 175-180.

35. Wang, C.N.; Guo, X.H.; Ma, M.Z.; Li, J.D. Ore-forming geological background of K-Mg salt in Qarhan Salt Lake. Northwest. Geol. 2008, 1, 97-106.

36. Qinghai Institute of Salt Lakes. Methods for Analysis of Brine and Salt; Science Press: Beijing, China, 1973.

37. Noh, H.; Hub, Y.; Qin, J.H.; Ellis, A. Chemical weathering in the Three Rivers region of Eastern Tibet. Geochim. Cosmochim. Acta. 2009, 73, 1857-1877. [CrossRef]

38. Xiao, J.; Jin, Z.D.; Ding, H.; Wang, J.; Zhang, F. Geochemistry and solute sources of surface waters of the Tarim River Basin in the extreme arid region, NW Tibetan Plateau. J. Asian Earth Sci. 2012, 54, 162-173. [CrossRef]

39. Wu, W.H. Hydrochemistry of inland rivers in the north Tibetan Plateau: Constraints and weathering rate estimation. Sci. Total Environ. 2016, 541, 468-482. [CrossRef] [PubMed]

40. Galy, A.; France-Lanord, C. Weathering processes in the Ganges-Brahmaputra basin and the riverine alkalinity budget. Chem. Geol. 1999, 159, 31-60. [CrossRef]

41. Moon, S.; Huh, Y.; Qin, J.; Van Pho, N. Chemical weathering in the Hong Red River basin: Rates of silicate weathering and their controlling factors. Geochim. Cosmochim. Acta 2007, 71, 1411-1430. [CrossRef]

42. Jiang, H.; Liu, W.J.; Xu, Z.F.; Zhou, X.D.; Zheng, Z.Y.; Zhao, T.; Zhou, L.; Zhang, X.; Xu, Y.F.; Liu, T.Z. Chemical weathering of small catchments on the Southeastern Tibetan Plateau I: Water sources, solute sources and weathering rates. Chem. Geol. 2018, 500, 159-174. [CrossRef]

43. Xu, Z.; Liu, C.Q. Water geochemistry of the Xijiang basin rivers, South China: Chemical weathering and $\mathrm{CO}_{2}$ consumption. Appl. Geochem. 2010, 25, 1603-1614. [CrossRef]

44. Stallard, R.F.; Edmond, J.M. Geochemistry of the Amazon: 2. The influence of geology and weathering environment on the dissolved load. J. Geophys. Res. 1983, 88, 9671-9688. [CrossRef] 
45. White, A.F.; Blum, A.E. Effect of climate on chemical weathering in watersheds. Geochim. Cosmochim. Acta 1995, 59, 1729-1747. [CrossRef]

46. Gaillardet, J.; Dupre, B.; Louvat, P.; Allegre, C.J. Global silicate weathering and $\mathrm{CO}_{2}$ consumption rates deduced from the chemistry of large rivers. Chem. Geol. 1999, 159, 3-30. [CrossRef]

47. Tan, H.B.; Liu, X.Q.; Yu, S.S.; Lyu, Y.P. Character of Hydrochemistry in Golmud River-Dabsan Lake Water. J. Lake Sci. 2001, 13, 43-50.

48. Du, Z.M. Hydrochemical changes of waters from the upper-middle reaches of Golmud river and their influencing factors. J. Salt Lake Res. 2018, 1, 25-31.

49. Zhu, Y.Z.; Li, Z.Y.; Wu, B.H.; Wang, M.L. The formation of the Qarhan saline lakes as viewed from the Neotectonic movement. Acta Geol. Sin. 1990, 1, 13-21.

50. Zhu, Y.Z.; Zhong, J.H.; Li, W.S. Neotectonic Movement and Evolution of Saline Lakes in the Qaidam Basin; Geological Press: Beijing, China, 1994.

51. Liu, C.L.; Wang, M.L. Evaluation of Quaternary depositional environments and forming of potash deposits in Lop lake, Xinjiang, China. Acta Geosci. Sin. 1999, 20, 264-270.

52. Chen, K.Z.; Yang, S.X.; Zheng, X.Y. Salt lakes in the Tebet Plateau. Acta Geol. Sin. 1981, 1, 13-21.

53. Guo, P.; Liu, C.Y.; Huang, L.; Yu, M.L.; Wang, P.; Zhang, G.Q. Palaeohydrological evolution of the late Cenozoic saline lake in the Qaidam Basin, NE Tibetan Plateau: Tectonic vs. climatic control. Glob. Planet. Chang. 2018, 165, 44-61. [CrossRef]

54. Yuan, J.Q.; Huo, C.Y. Genesis of the sylvinite deposits in the Qarhan Salt Lake, Qinghai province. Earth Sci. 1981, 1, 207-213.

55. Yu, J.Q.; Gao, C.L.; Cheng, A.Y. Geomorphic, hydroclimatic and hydrothermal controls on the formation of lithium brine deposits in the Qaidam Basin, northern Tibetan Plateau, China. Ore Geol. Rev. 2013, 50, 171-183. [CrossRef]

56. Craig, H. Isotopic variations in meteoric waters. Science 1961, 133, 1702-1703. [CrossRef] [PubMed]

57. Xiao, Y.; Shao, J.L.; Frape, S.K.; Cui, Y.L.; Dang, X.Y.; Wang, S.B.; Ji, Y.H. Groundwater origin, flow regime and geochemical evolution in arid endorheic watersheds: A case study from the Qaidam Basin, northwestern China. Hydrol. Earth Syst. Sci. 2018, 22, 4381-4400. [CrossRef]

58. $\mathrm{Xu}, \mathrm{W}$. Groundwater Cycle Patterns and its Response to Human Activities in Nalenggele Alluvial-Proluvial Plain. Ph.D. Thesis, Jilin University, Changchun, China, 2015.

59. Carpenter, A.B. Origin and Chemical Evolution of Brines in Sedimentary Basins. Proceedings of the SPE Annual Fall Technical Conference and Exhibition, Houston, TX, USA, 1-3 October 1978; Ohnson, K.S., Russell, J.A., Eds.; Society of Petroleum Engineers: Houston, TX, USA, 1978; pp. 60-77.

60. $\mathrm{Xu}, \mathrm{C}$. Preliminary study on clay minerals and their significance in sediment profile of some salt lakes in Qaidam Basin. Acta Sedimentol. Sin. 1983, 3, 123-127.

61. Bjorkum, G. A chemical model of the formation of authigenic kaolinite, potassium feldspar, and illite in sediments. Transl. Geol. Sci. 1989, 3, 6-11.

62. Gao, X. Clay Mineralogy; Chemical Industry Press: Beijing, China, 2017.

63. Kharaka, Y.K.; Gunter, W.D.; Aggarwal, P.K.; Perkins, E.H.; Debraal, J.D. A Computer Program for Geochemical Modeling of Water-Rock Interations; USGS Water Resources Invest: Menlo Park, CA, USA, 1988; p. 420.

64. Zheng, Y.F.; Chen, J.F. Stable Isotopic Geochemistry; Science Press: Beijing, China, 2000.

65. Guo, P.; Liu, C.Y.; Huang, L.; Wang, P.; Wang, K.; Yuan, H.L.; Xu, C.K. Genesis of the late Eocene bedded halite in the Qaidam Basin and its implication for paleoclimate in East Asia. Paleogeogr. Paleoclimatol. Paleoecol. 2017, 487, 364-380. [CrossRef]

(C) 2019 by the authors. Licensee MDPI, Basel, Switzerland. This article is an open access article distributed under the terms and conditions of the Creative Commons Attribution (CC BY) license (http://creativecommons.org/licenses/by/4.0/). 